\title{
A THEORETICAL APPROACH TO THE FORMATION OF SUBJECTS' INTERACTION IN SUPPLY CHAINS AT RISKS CONDITIONS
}

\author{
Yuliia Remyha', Oksana Pozniak ${ }^{2}$ \\ National Aviation University, Ukraine
}

\begin{abstract}
The purpose of the paper is to develop the substantiation of a multilevel subjective interaction of market logistics services participants taking into account the risks conditions in supply chains. Methodology. The research is based on the use of the following general scientific and special research methods: the system and process approach - to substantiate the theoretical positions to formation of multilevel subjective interaction and the concept of risk management in the supply chains; methods of logical-dialectical analysis - for the disclosure of the theoretical and conceptual provisions of the supply chain management and the determination of the relationship between main entities (participants) and the logistics operator in the supply chains at risks conditions. Results of the research showed that three levels of subjective interaction between market participants of logistics services in supply chains could be formed. In this situation, there is a possibility to identify aspects and sources of increasing the efficiency of business processes' integration in supply chains according to micro, meso, and macro levels. Practical implications. The development of an adaption system to risk situations in the system logistics integrator activity (operator of the logistics market) which includes identification subsystems, prevention of the occurrence conditions, risks localization and dissipation, as well as procedures and methods for compensating for risk losses, allows adjusting the logistics operator's activities in real time and evaluate its contribution to the performance of the supply chain. Value/originality. The value of the research is to determine the exclusive role of the system logistics integrator as the main interaction subject in the market of logistics services and the grading subject of systemic risks in the supply chain.
\end{abstract}

Key words: supply chain, supply chain entities, logistics provider, logistics operator, system logistic integrator, risks conditions, risk management system, adaption system to risk situations.

JEL Classification: D01, D16, D70, D9, F02, F15, L21, M2, R40

\section{Introduction}

In the context of globalization, the process of interaction of economic actors in the supply chain always occurs under uncertainty, therefore, there are risks. Identification and competent risk management are necessary to ensure the sustainability of the organizations themselves and the entire supply chain that are formed as a result of this interaction. Effective interaction of actors based on a long-term basis requires the consistency of interests of all participants in the supply chain and determines risk management system creation. The identification of risks of the supply chain makes it possible to model the options for interaction with the subjects and to predict the results of this interaction.

Consequently, the risk management system creation allows increasing the efficiency of logistics enterprises, to find ways of rational use of resources and to effectively apply logistics approaches to the practical activities of enterprises. This leads to an increase in the manageability of the supply chain, the certainty of the terms of interaction, the reduction of losses time, money, and all types of resources.

Today long-term and close partnerships between the supplier and the consumer are needed to meet differentiated needs of end-users and development of the potential utility of the proposal and the pooling of efforts to increase it for the successful and efficient functioning of the supply chain (Harrison, Hoek, 2007). The partnership should be based on mutually agreed goals aimed at achieving the overall economic effect (Lysons, Gillingham, 2005). The main objective of the partnership relationship between logistics companies is the transformation of long-term relationships that will be built on mutual trust, where quality, innovation, planning of delivery chains, management of transport

\footnotetext{
Corresponding author:

${ }^{1}$ Logistics Department, National Aviation University.

E-mail: remyga julia@ukr.net

${ }^{2}$ Logistics Department, National Aviation University.

E-mail: poznyak_ov@ukr.net
} 
risks, jointly created added value harmoniously complement the competitive price of goods or services (Harrison, Hoek, 2007).

\section{Investigating the activities of logistics operators in supply chains}

Management of all the necessary processes of logistics enterprises based on a practical understanding of the economic and synergistic effect of the logistics concept, not only for transportation or providing storage services in the domestic market but also as a global phenomenon, which meets with the uncertainty demands or risks in the international foreign market.

The dynamic development of the Ukrainian market shows that logistics companies are trying to satisfy the needs and desires of consumers when using the full range of services, using modern information technologies and technical equipment, experience of leading foreign companies, while expanding the scope of their activities to increase profitability and other economic indicators, which characterize the competitiveness of the organization.

Previously, Ukrainian logistics companies had an opportunity to operate on a single domestic market or within a single region. Such regionalization of the enterprise's activity could bring significant competitive advantages. However, enterprises that want to grow, flourish, do not consider narrow regional specialization as a competitive advantage. Time is required to change its activities, to change development strategies - to enter the international market. In other words, there is more and more such a concept among enterprises as "integration of supply chain management".

The concept of the supply chain also affected the development and integration of the participants and it actualized the evolution of the supply chain objectives with the evolution of the logistics operator essence (see Figure 1).

The intensive development of supply chains by the turn of the century has led to the expediency of using a special entity for managing the supply chain as an activity integrator - the logistics operator. Such a logistics company (operator) should integrate all functions related to the process of supplying products, form the optimal composition of integrated facilities, technologies, experience, and knowledge, coordinate logistics processes along the entire supply chain, and manage changes in the structure of the entire supply chain under uncertainty, implementing all their functions as moderators of this process.

Effective functioning of the supply chain needs longterm and stable relations system. To fulfil this condition, it is necessary to ensure the performance of such indicators as (Stock, Lambert, 2005):

- failure is the likelihood of non-refusal when executing orders received from consumers within a fixed time;

- longevity is the property of the chain and its constituent parts to remain operational over a long

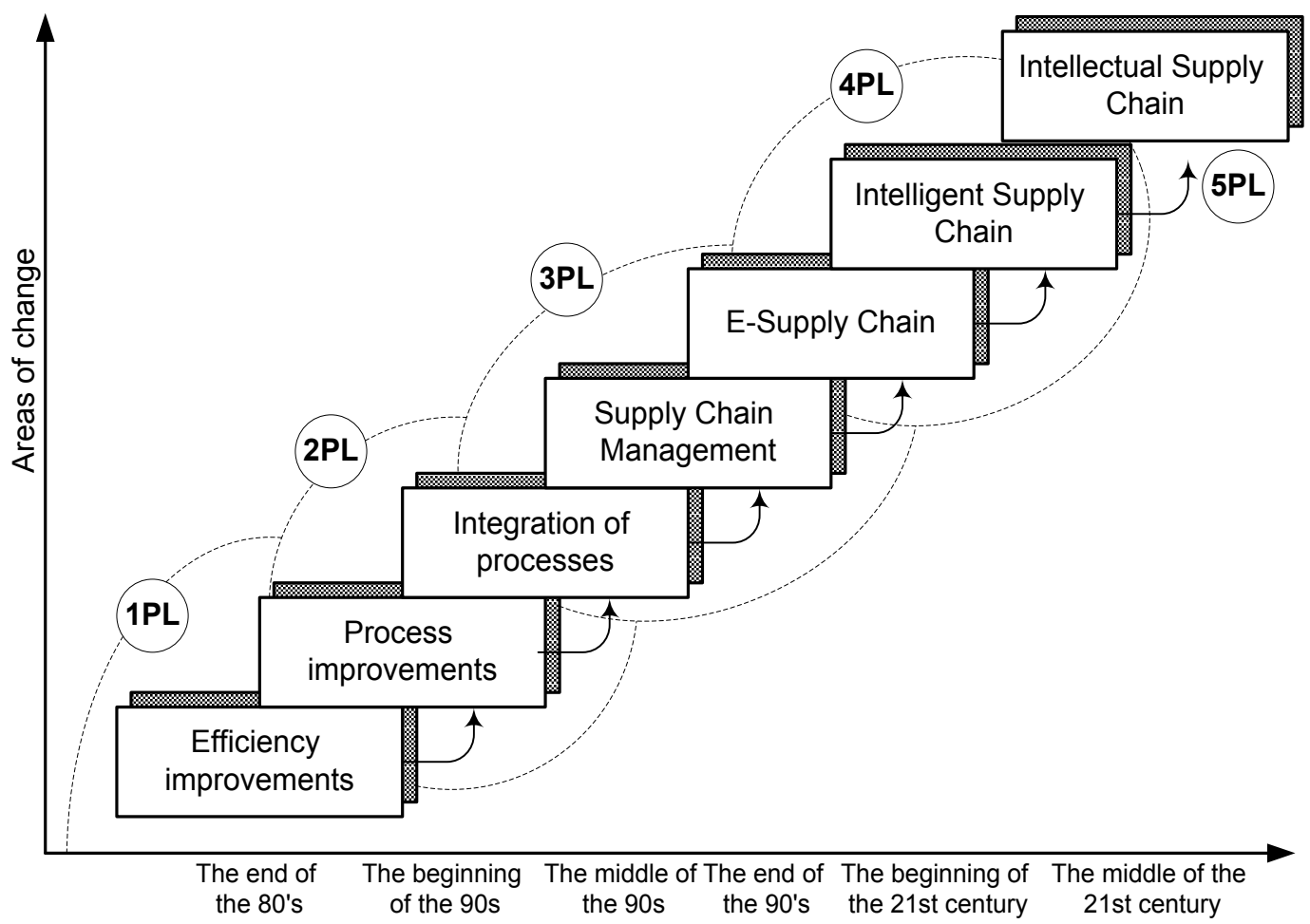

Fig. 1. Stages of the supply chain evolution

Source: revised by author based on data (Krikavskij, 2006) 
period of time, operating in the average conditions (without overloads);

- preservation is the ability of the chain and its parts to maintain efficiency after reservation, conservation or functional reconstruction.

Thus, the main driving forces for the development of supply chains at the present stage is the time factor that determines the need to accelerate the movement of material flow in the supply chain, as well as the space factor, namely the location and location of objects of logistics control (Chuhray, Hirna, 2007). It can be argued that an integrated approach to the formation of supply chains will help to achieve competitive advantages in the sphere of circulation, in the sphere of expenses, in the sphere of sales of products to all entities of this supply chain.

From this, it follows that still, the main way to prevent negative consequences in the activities of logistics companies is to consider the logistics chain not as a set of separate functional activities, but as their integrated system, which requires the unity of management of the entire supply chain (see Figure 2).

Thus, Supply Chain Management (SCM) is a complex, interactive, process, and system approach to managing all operations, from the place of supply of resources to the place of consumption. The main objective of the supply chain management should be to maximize the competitiveness and profitability of the enterprise (that is, the entire structure of the chain), taking into account the preferences of the end-user. In this regard, we can say that the integration of all processes within the supply chain should be aimed at increasing the overall efficiency of all participants in the supply chain.
It should also be noted that SCM is a complex process that is difficult to implement ideally in practice, as there are many difficulties encountered by the company in the operation of the company, which start from suppliers, continue during production, and end at the stage of consumption of goods and services.

SCM is mainly focused on the integration of processes implemented by partners within the supply chain, where the final customer is the main user (Gattorna, 1998). The level of consumer satisfaction depends on the management of material and information flows throughout the supply chain. If the delivery period is broken or the product is not in stock, the entire logistics chain becomes vulnerable to competitors, as it can more logistically fulfil the task (Stock, Lambert, 2005).

\section{Development of logistics integrator in the supply chains}

The integration of key business processes is primarily important for improving integrated planning and controlling SCM.

Integration as the principle of interaction in SCM can be viewed on three levels of micro, meso, and macro (see Figure 3).

Integration of business processes at the micro level is based on the principles of strategic interaction between the Focus Company and suppliers and customers. The difference from traditional forms of organization and management lies in the synchronization and integration of key business processes and planning and management models on the basis of a single information platform

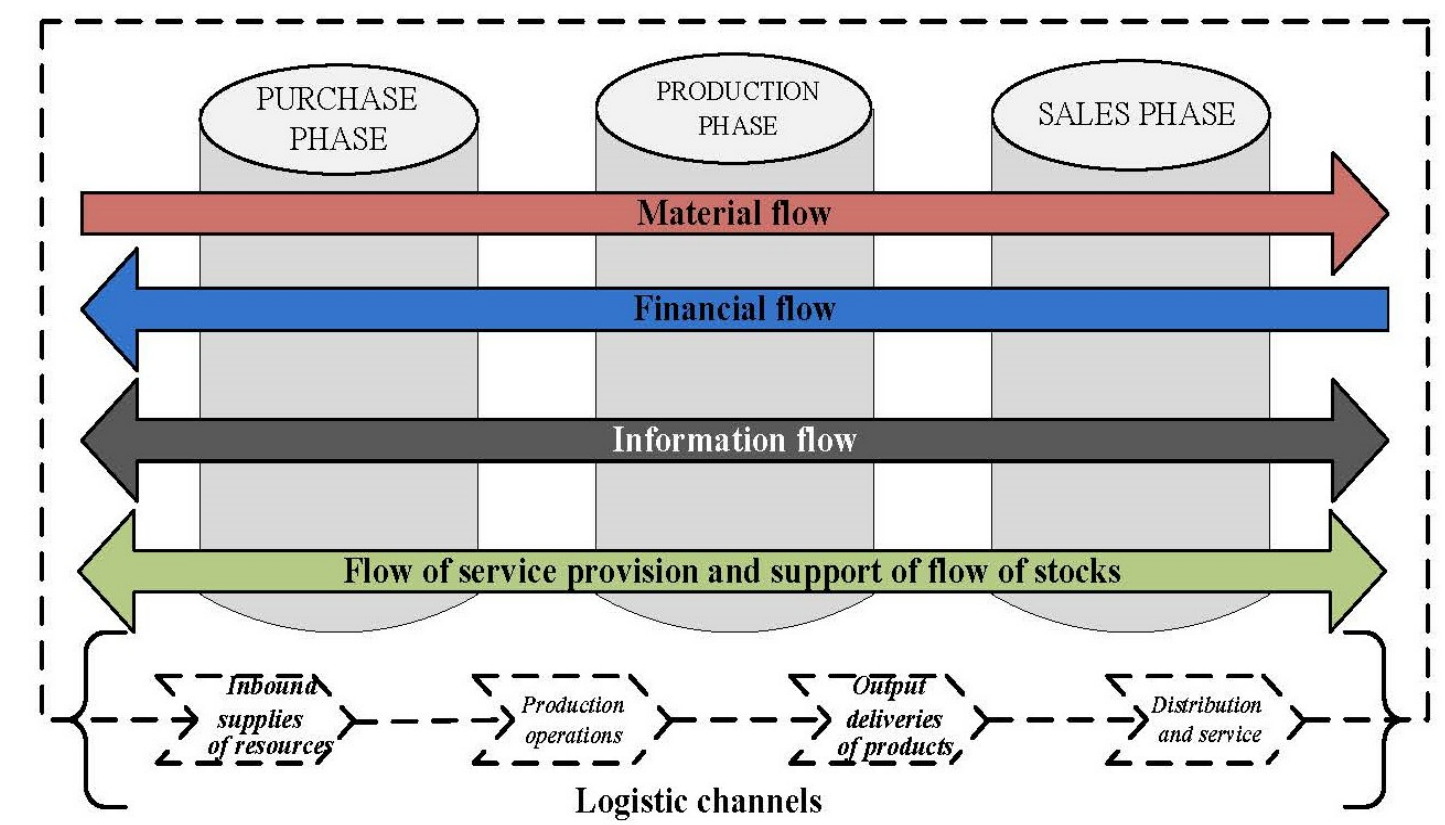

Fig. 2. An integrated approach to supply chain management

Source: own research 
with suppliers and customers throughout the supply chain (Smirnova, 2009).

\begin{tabular}{|cl|}
\hline Macro & $\cdot$ Directly supply chains \\
\hline Meso & $\begin{array}{l}\text { - Subjects of the supply } \\
\text { chain }\end{array}$ \\
\hline Micro & $\begin{array}{l}\text { ・ Business processes in } \\
\text { the logistics system }\end{array}$ \\
\hline
\end{tabular}

Fig. 3. Levels of integration in supply chains

Source: own research

Obstacles to integration in supply chains at the micro level (Volkov, 2011):

1. The concentration of one-off transactions to the detriment of long-term cooperation.

2. The insufficient intensity of goods and services flows in the mode of execution of orders of participants in supply chains.

3. The inconsistency of the organizational structure of the company with the methods of managing logistics processes on a cross-functional basis.

4. The effect of market and competitive barriers, such as restrictions on market entry, inadequate access to the market, commercial and other information, pricing, competition rules.

5. Unsettled relationships with business partners, due, for example, to different approaches to solving issues related to transportation, cargo handling, storage, information exchange, etc.

6. Financial barriers that flow from the problems of the financial and economic state of companies due to errors in forecasting, possible actions of competitors, seasonal fluctuations.

Let's consider aspects and sources of the effective integration of business processes in supply chains in Table 1.

In modern conditions of market relations, there are various forms of integration of economic entities in the field of logistics services: contracts for integrated supply and sales management, organization of public warehouses and distribution centres, integration in management activities, formation of associations, consortiums, alliances, and unions in the field of logistics management, as well as in the creation of favourable conditions for the implementation of economic activities and the removal of mutual barriers.

Let's consider the basic market advantages that allow us to realize the development of a strategy for integrating logistics companies in supply chains in Table 2.

Preliminary conditions for the effective interaction of business partners in the conditions of cooperation are formulated (Lukinskiy, Panova, Strimovskaya 2017):

- the willingness of partners to cooperate on the basis of understanding their role in the logistics system;

- application of advanced transport process technologies and terminal processing, which is determined by the state of the infrastructure;

- mutual trust;

- opportunities to achieve transparency in the costs of partners in the performance of joint work.

Also, the logistics company's orientation to strategic cooperation with business partners requires differentiated work with clients - not only with the already serviced company but also potential ones - that fall within its competence and can be attracted through partnerships with other operators.

Each supply chain within one industry is linked to other supply chains in the areas of coincidence of interests (the intersection of flows) of its counterparties: identical purchased products or services (Svon, 2017). It is rational to refer with arguments that the benefits of integration can be obtained not only within a single supply chain but also between different supply chains of one or several industries (see Figure 4).

The idea of global integration of counterparties of various supply chains is to create a single information system for the search and management of data on sales and stocks of all counterparties participating in the system (see Figure 5, Figure 6).

To ensure integration between supply chains, two modules should be identified (Potaman, 2013):

1. Performance management - the module contains information on the performance of counterparts integrated into the system and serves to calculate KPI for each supply chain counterpart and identify bottlenecks.

2. Unified information platform - the module contains information on the integrable counterparty, the supply chain to which it relates, and serves to:

Table 1

Aspects and sources of increasing the integration efficiency of business processes in supply chains

\begin{tabular}{|l|l|}
\hline \multicolumn{1}{|c|}{ Aspects of increasing efficiency } & \multicolumn{1}{c|}{ Sources of efficiency improvement } \\
\hline $\begin{array}{l}\text { Mutually beneficial and long-term } \\
\text { cooperation of participants in the chain; }\end{array}$ & $\begin{array}{l}\text { Increase the accuracy of planning through unified information channels, synchronization of } \\
\text { business processes, joint demand forecasting. }\end{array}$ \\
\hline $\begin{array}{l}\text { Reducing risks and increasing the reliability } \\
\text { of plans and supplies; }\end{array}$ & $\begin{array}{l}\text { Improving the quality of operational management through continuous monitoring of the } \\
\text { entire supply chain, timely identification of deviations and irregularities in the functioning } \\
\text { of the supply chain. }\end{array}$ \\
\hline Reduction of overhead and transaction costs. & $\begin{array}{l}\text { Using standardized procedures, documents allow you to eliminate duplication of effort and } \\
\text { transmitted information. }\end{array}$ \\
\hline
\end{tabular}

Source: own research 
Table 2

Forms of integration in supply chains at the meso level

\begin{tabular}{|c|c|c|}
\hline $\begin{array}{l}\text { Forms of integration of enterprises } \\
\text { in the industry }\end{array}$ & Examples of cooperation & $\begin{array}{l}\text { Advantages and disadvantages of the } \\
\text { form of integration }\end{array}$ \\
\hline $\begin{array}{l}\text { Informal agreements of } \\
\text { enterprises on the joint fulfilment } \\
\text { of certain actions }\end{array}$ & $\begin{array}{l}\text { For example, companies can jointly purchase goods to } \\
\text { receive discounts for the volume of purchases; combine } \\
\text { cargo for transportation, reducing transportation costs; } \\
\text { coordinate the size of the package to facilitate cargo } \\
\text { handling; use general lists of preferred suppliers, etc. }\end{array}$ & $\begin{array}{l}\text { The advantages of such relationships } \\
\text { include flexibility and lack of } \\
\text { commitment }\end{array}$ \\
\hline $\begin{array}{l}\text { Formal agreements of enterprises } \\
\text { on the basis of written contracts } \\
\text { establishing the obligations of } \\
\text { each party; formation of a strategic } \\
\text { union or partnership }\end{array}$ & $\begin{array}{l}\text { The basis for the formation of such unions is mutually } \\
\text { beneficial joint work in the past when the enterprises } \\
\text { have the confidence that none of them will be able to win } \\
\text { if they begin to interact with other partners. Strategic } \\
\text { alliances provide for long-term obligations of the parties, } \\
\text { which guarantee future orders and deliveries. For example, } \\
\text { suppliers can reduce the range of products produced by } \\
\text { releasing the remainder with the highest possible efficiency } \\
\text { or concentrate on providing a small number of services, but } \\
\text { of very high quality. Customers also reduce the number of } \\
\text { their suppliers, because they are confident in partners and } \\
\text { that they do not have to look for more profitable options. }\end{array}$ & $\begin{array}{l}\text { However, either party can terminate } \\
\text { cooperation without warning at any } \\
\text { time convenient for it }\end{array}$ \\
\hline Virtual enterprise & $\begin{array}{l}\text { The virtual partnership is a computer-integrated organization } \\
\text { of economic entities in cooperative relationships, i.e. } \\
\text { which work together and coordinate actions for profit. } \\
\text { Such partnership is based on the formation of a single } \\
\text { organizational, technological, and information environment } \\
\text { through the temporary pooling of resources of various } \\
\text { enterprises. The virtual enterprise itself is not a legal entity; it } \\
\text { can only be a coordinating body: for example, a management } \\
\text { company that does not directly participate in the production } \\
\text { and logistics process or one of the enterprises participates in } \\
\text { the partnership, which is the main executor for a particular } \\
\text { project. }\end{array}$ & $\begin{array}{l}\text { Advantages: } \\
\text { 1. Decentralization, distribution and } \\
\text { availability of mechanisms for the } \\
\text { flexible formation of new organizational } \\
\text { structures. } \\
\text { 2. Ability to quickly adapt to changing } \\
\text { market requirements. } \\
\text { 3. Self-regulation and self-organization, } \\
\text { coordination and interaction on the } \\
\text { basis of business processes. } \\
\text { 4. Cooperation contributes to sharing } \\
\text { risks between participants and reducing } \\
\text { uncertainty } \\
\text { Disadvantages: } \\
\text { 1. It induces the creation of new risks } \\
\text { related to the interaction of enterprises. }\end{array}$ \\
\hline
\end{tabular}

Source: own research

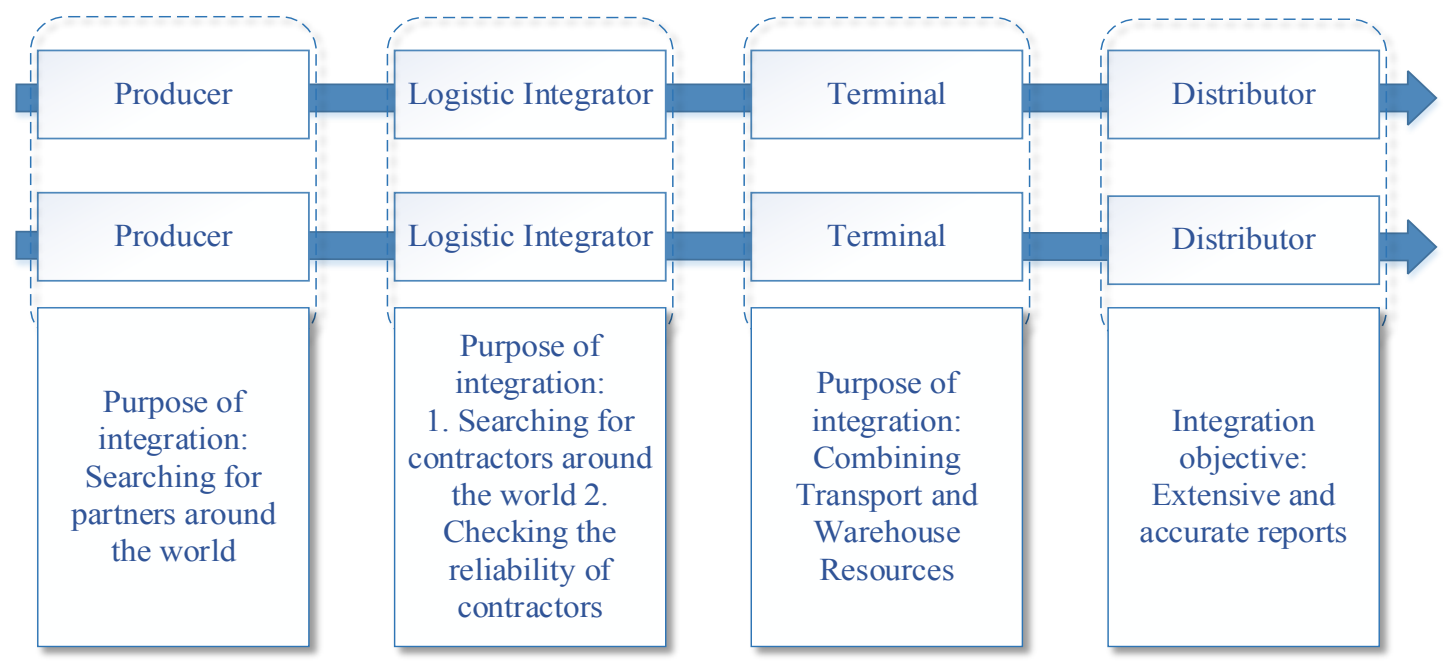

Fig. 4. Schematic representation of the different supply chains integration

Source: own research 


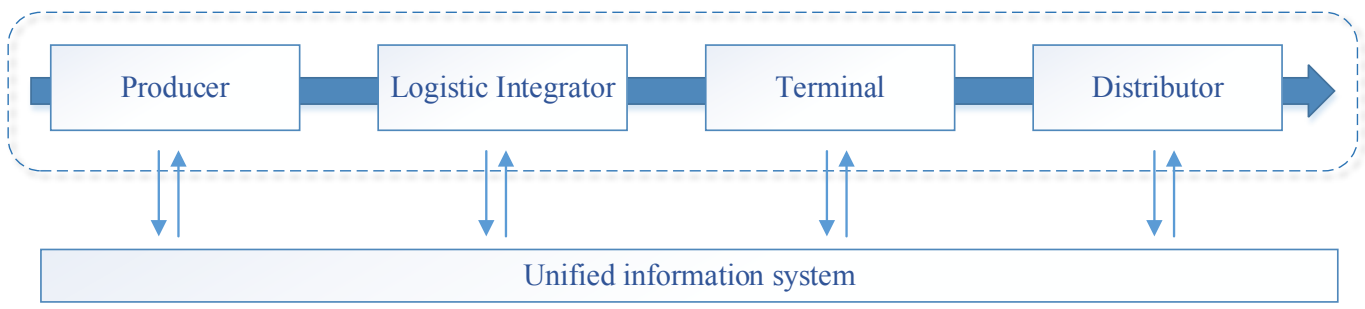

Fig. 5. Illustration of the system operation at the level of one supply chain

Source: own research

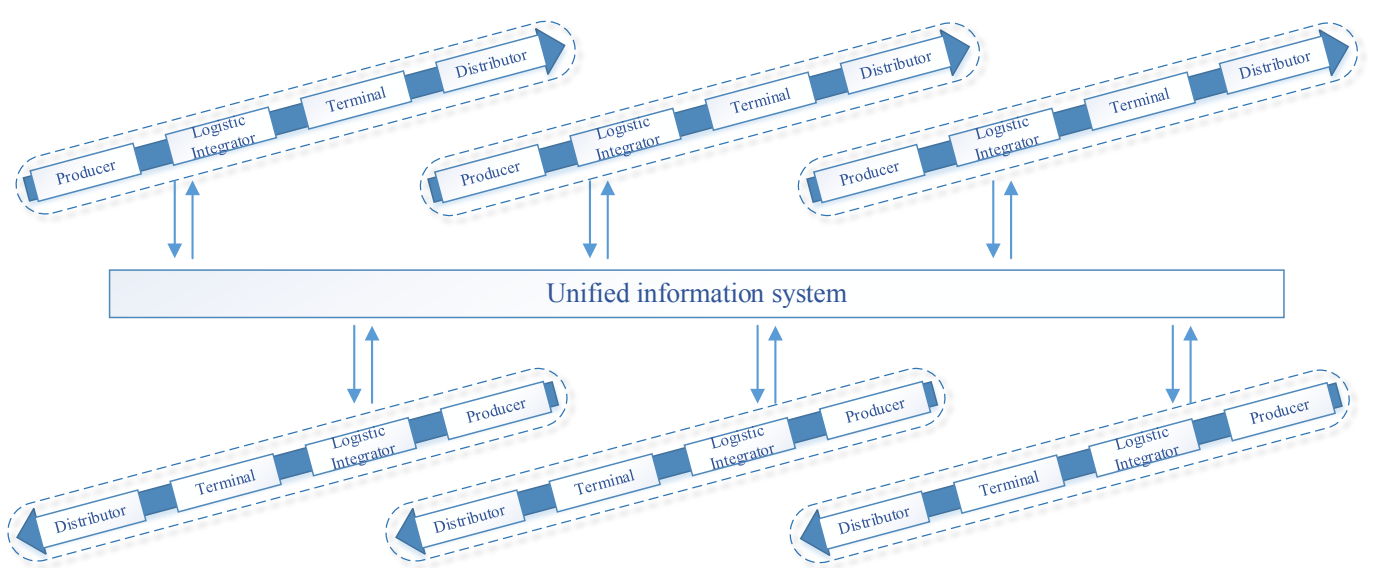

Fig. 6. Illustration of the system operation at the level of several supply chains

Source: own research

a) compiling a catalogue of firms to find partners for each task;

b) creation of an electronic platform for tenders.

For the organization of a common resource, which consolidates on continuous basis information from each link of the supply chain, the following principles/ conditions must be fulfilled:

- counterparties establish distinctions on the availability of information to other contractors of supply chains, both in the form of information and for each specific counterparty;

- access to information in the system is only after integration of the counterparty into the system (providing data on a daily basis).

Let's look at three levels of integration in the scheme (see Figure 7).

According to this scheme, a new subject of the supply chain appears - a system logistic integrator. The system logistic integrator is an intermediary specializing in organization and planning of commodity circulation within the framework of an organizational form of the economic flow (chain, network, channel, web) that implements a sequence of actions related to the coordination of flow processes between various elements - supply chain entities.

Duties of the system logistics integrator (Sabatkoev, Sultanov, 2012):
1. Administers information flows from the client to the suppliers and back;

2. Integrates IT systems of counterparties in the supply chain: defines the interface, provides standardized electronic data interchange and data integration in IT systems of companies.

3. Forms an analytical and statistical centre to support logistics solutions.

4. Provides monitoring and coordination of traffic flows.

5. Coordinates the sphere of customs clearance in the logistics chain.

6. He is the manager of the quality system of all processes, including information, forecasting.

The rights of a system logistics integrator:

1. Receive timely and truthful information from all participants in the supply chain.

2. Has an access to a complete and reliable package of documents for cargo from the cargo owner.

3. Has the right to choose contractors who will carry out business processes in the supply chain.

4. To close access to a single information system to contractors with whom, for objective reasons, cooperation does not continue.

5. Has the right to recover damages if they are incurred as a result of the actions of contractors.

Advantages of the integrated system for the customer (Sergeev, 2015): 


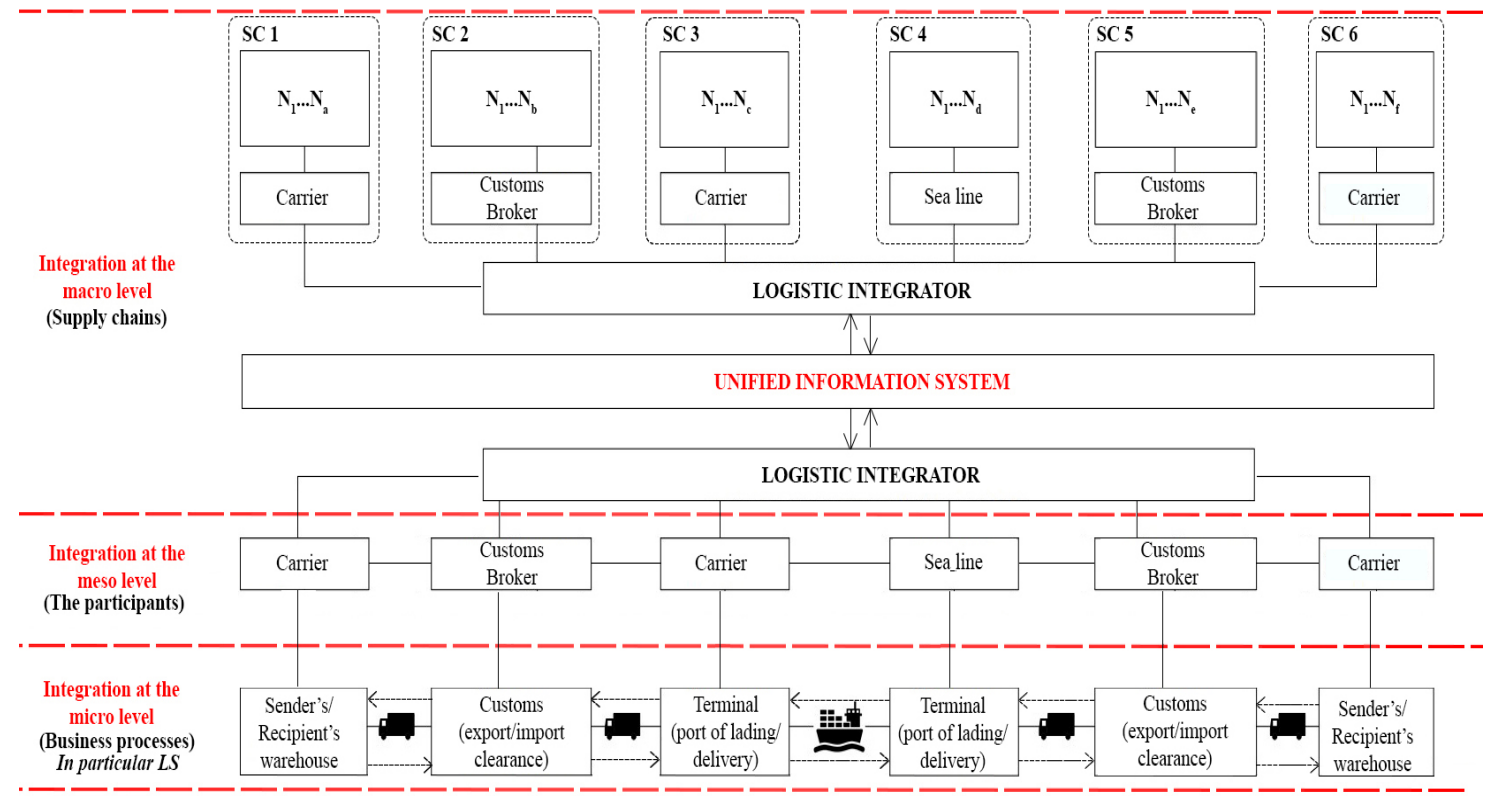

Fig. 7. Levels of integration in the supply chain

Source: own research

1. Acquires a permanent and reliable partner (longterm contract).

2. Communicates with only one service provider the principle of a "single window".

3. Gets a clear vision of his logistics budget.

4. Gets transparency in the processes.

5. Gets an opportunity to continuously improve processes and optimize logistics costs.

Globalization processes in the world economy led to the need for global management of logistics systems. Some experts see the future of logistics in the association of separate self-managed networks, which together form a global logistics system.

These trends make it extremely important for logistics operators to be able to optimally set up and manage logistics processes at all levels of supply chain integration, thereby helping to minimize costs.

\section{Risk management system in supply chains}

In the supply chain, the partnership is a kind of relationship between partner companies that are characterized by openness, mutual trust, sharing of risks and benefits, which contributes to the efficient functioning of the chain as a whole.

It should be remembered that the construction of the supply chain of a particular enterprise is individual in nature, so it affects the emergence of risks that had to be analysed, identified and eliminated by these "bottlenecks" in the supply chain.

In turn, Hau L. Lee, the scientist and co-director of the Global Supply Chain Management Forum at Stanford University, claimed that managing the risks in supply chains on the global market is possible for those companies that will build their operations on the principles of three "A": agility, adaptability, alignment (see Figure 8).

Effective use of the benefits and levelling up of all the risks to the supply chain actors requires an effective risk management tool that will enable identification, diagnosis, monitoring, and development of a set of measures for the implementation of preventive, corrective, and managerial actions to address all possible uncertainties, which arise (or may arise) in the process of satisfying the needs of consumers with the supply chain participants in the conditions of global market instability distillation.

The process of risk management, in the supply chain, should be systemic, timely, take into account multifactor effects and multivariate solutions, respond to the situation in the market. Trends and strategies of the transport market actors should be aimed at strengthening the responsibility of interacting enterprises. This, in turn, will simplify the schemes of the interaction of all subjects of the process of cargo transportation. It will also allow logistics companies to reduce the risks of their activities by optimizing procedures at the most costly and problematic stages of traffic flow, as well as to reduce overall logistics costs.

Summarizing the methodological approaches to the risk management process has made it possible to establish that risk management should be carried out according to the following principles (Vitlinskiy, Velikoivanenko, 2004):

- the principle of maximum coverage (involves the desire for the broadest analysis of possible causes and factors of risk); 


\begin{tabular}{|c|c|c|}
\hline AGILITY & ADAPTABILITY & ALIGNMENT \\
\hline Purpose & Purpose & Purpose \\
\hline $\begin{array}{l}\text { Quickly respond to short- } \\
\text { term changes in demand or } \\
\text { supply; organically cope } \\
\text { with violations of normal } \\
\text { environmental conditions }\end{array}$ & \begin{tabular}{|} 
To adjust structure of \\
supply chain taking into \\
account structural changes \\
in the markets; make \\
changes to the supply \\
network in accordance with \\
the strategies and \\
$\Rightarrow$ technologies
\end{tabular} & $\begin{array}{c}\text { Create incentives to } \\
\text { improve business } \\
\text { performance }\end{array}$ \\
\hline Methods & $\begin{array}{l}\text { technologies } \\
\text { Methods }\end{array}$ & Methods \\
\hline $\begin{array}{l}\text { 1. Creation and support of } \\
\text { information flow between the } \\
\text { enterprise, suppliers and clients. } \\
\text { 2. Development of cooperation with } \\
\text { suppliers. } \\
\text { 3. Planning operations on the } \\
\text { principle of diversification. } \\
\text { 4. Creation of reserves in the form of } \\
\text { inexpensive stocks, but as important } \\
\text { components. } \\
\text { 5. Availability of a reliable logistics } \\
\text { system. } \\
\text { 6. Develop an action plan in } \\
\text { uncertain situations and form groups } \\
\text { of crisis management. }\end{array}$ & $\begin{array}{l}\text { 1. Tracking situations in the } \\
\text { economies of different countries to } \\
\text { identify new markets. } \\
\text { 2. Attracting intermediaries to find } \\
\text { new vendors and logistics } \\
\text { infrastructure. } \\
\text { 3. Evaluate the needs of end users, } \\
\text { not just direct customers. } \\
\text { 4. Ensuring flexibility in the } \\
\text { production process. } \\
\text { 5. Determination of the stage of the } \\
\text { technological and life cycle of the } \\
\text { company's products. }\end{array}$ & $\begin{array}{l}\text { 1. Freely exchange information and } \\
\text { knowledge with suppliers and } \\
\text { customers. } \\
\text { 2. Clear definition of functions, tasks, } \\
\text { responsibilities for suppliers and } \\
\text { customers. } \\
\text { 3. Clear distribution of risks, costs, } \\
\text { revenues in accordance with the } \\
\text { programs of improving the } \\
\text { enterprise's activities. }\end{array}$ \\
\hline & $\nabla$ & \\
\hline 111 & CHAIN AT RISKS C & IONS \\
\hline
\end{tabular}

Fig. 8. Principles of levelling risks in the supply chain

Source: completed by author based on (Hau L. Lee, 2008)

- the principle of minimization (involves minimizing the types of possible risks and minimizing the degree of risk exposure to the activity);

- the principle of adequate reaction (provides an adequate and rapid response to changes that may lead to a risk);

- the principle of reasonable acceptance (assumes that enterprises can assume only a reasonable risk).

Taking into account the mentioned principles of risk management in the activity of logistic operators should be based on:

1) construction of an integrated supply chain that simplifies the risk management tasks;

2) transition from the management of individual functions or operations to the integration of activities and the integration of all possible risks in the supply chain;

3) use of the system-process view of interaction and mutual influence of risks, which will provide an integrated approach to the formation of an anti-crisis system of counteraction to risk;
4) interaction and coordination of business processes in the equitable distribution of risks, costs and revenues among all participants in the supply chain.

We propose to consider a system of risk management as a set of mutually agreed methods, management tools, as well as procedures for making managerial decisions for the purpose of identifying, assessing, establishing causal relationships, developing managerial decisions for the prevention and neutralization of the consequences of a risk. Structurally, such a device may not be allocated separately to the administrative unit (department); it may represent a virtual organization of collective interaction of supply chain entities.

Generally, the creation of a risk assessment system in supply chains is a complicated and labour-intensive process, taking into account all the heterogeneity of indicators and the need for their respective choices. An essential requirement is to take into account the role of each individual segment which is suppliers, manufacturers, logistics operators and distributors. Such consistency will allow transparency to be provided 
while simultaneously identifying the most significant aspects of the activity.

The development of new strategies and organizational and economic measures for risk management in supply chains should be considered in modern conditions as a means of increasing the stability and profitability of the participants in the chain. Uncertainty in the supply chain cannot reliably guarantee the full implementation of the obligations of logistics enterprises to the customer. An important feature is the fact that no one can act alone if it deals with global (international) risks. Therefore, the result of the application of a universal risk management tool in the operation of the logistics operator should be the creation of an adequate system of counteracting modern threats.

The risk management process in the supply chains is designed to provide an efficient combination of the required functionality, cost-effectiveness and flexibility, and, as a result, the sustainable profitability of all members of the supply chain.

So, before you create a risk management system you need to:

- analyse the existing business processes of the logistics operator;

- find the main types of risk in business processes;

- clearly state the purpose, tasks, and requirements for risk assessment.

The main ways to reduce the risks in the activities of logistics operators can be called insurance, reservation (self-insurance), hedging, distribution, diversification, minimization (asset and liability management), avoidance (rejection of the risk transaction).

Therefore, taking into account the whole range of methods for reducing risk levels and the size of losses for enterprises, we are offered an adaptive risk management system in the activity of logistics operators (integrators) as an instrument of a process approach to timely adaptation of enterprises to the environment conditions for the correction of their activities and increase the efficiency of its operation in compliance with risk situations or events that should include such subsystems as identifying risk types, preventing their conditions in occurrence (avoidance of risks), localization of risks, dissipation (dispersion) of risks, as well as the elimination of the consequences of risk events (see Figure 9).

An important feature of the Adaption System to Risk Situations (ASRS) in the activities of logistics operators is the tendency to reduce costs, especially in the transportation of goods and their protection against various types of risks. Therefore, the result of the application of the ASRS will be prerequisite for the establishment of a stable delivery system. Such a system will provide effective control over the transportation of goods, the interaction of information flows, depending on the requirements of customers.

It should be noted that an important feature that defines the ASRS in the supply chain is the focus on reducing costs, especially when transporting goods and protecting them from various types of risks. In addition,

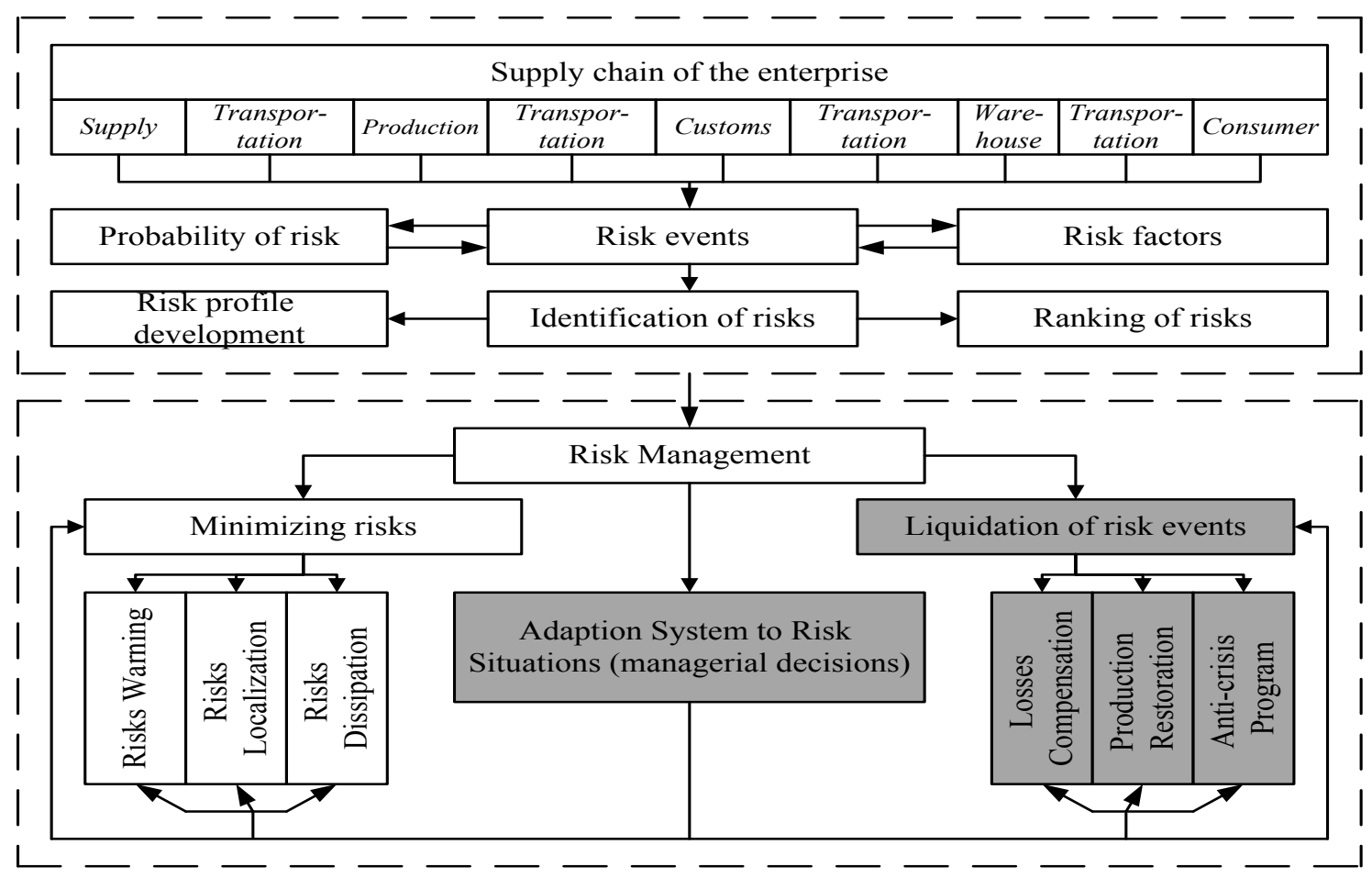

Fig. 9. Adaption System to Risk Situations in the activity of logistics operators

Source: own research 
it is necessary to systematically analyse and evaluate the identified deficiencies in the supply chains (see Figure 10).

Analysing this scheme, it should be determined that the main reasons for the strengthening of the role of partnership management and risk assessment in the supply chains are: increasing the level of responsibility of the logistics enterprises; increasing transparency of business; changes in international relations (including in international law); pressure from partners and the state; an increase in overall uncertainty in the business environment; ensuring continuity of supply; the desire to be more calm for all the supply processes.

The risk assessment procedure in supply chains will allow all participants to: create an additional value for the company due to factors such as cost savings; reduce risk losses by $10 \%-30 \%$; increase the predictability of financial indicators by stabilizing financial flows; increase the rating on the international scene; meet current international standards (Remyha, 2013).

\section{Conclusions}

Globalization and the integration of the world economy have led to the elimination of many traditional barriers to trade. There was an urgent need to develop international logistics coordination.

The system logistics integrator is an intermediary specializing in the organization and planning of commodity circulation within the framework of an organizational form of the economic flow (chains, networks, channels, webs) that implements a sequence

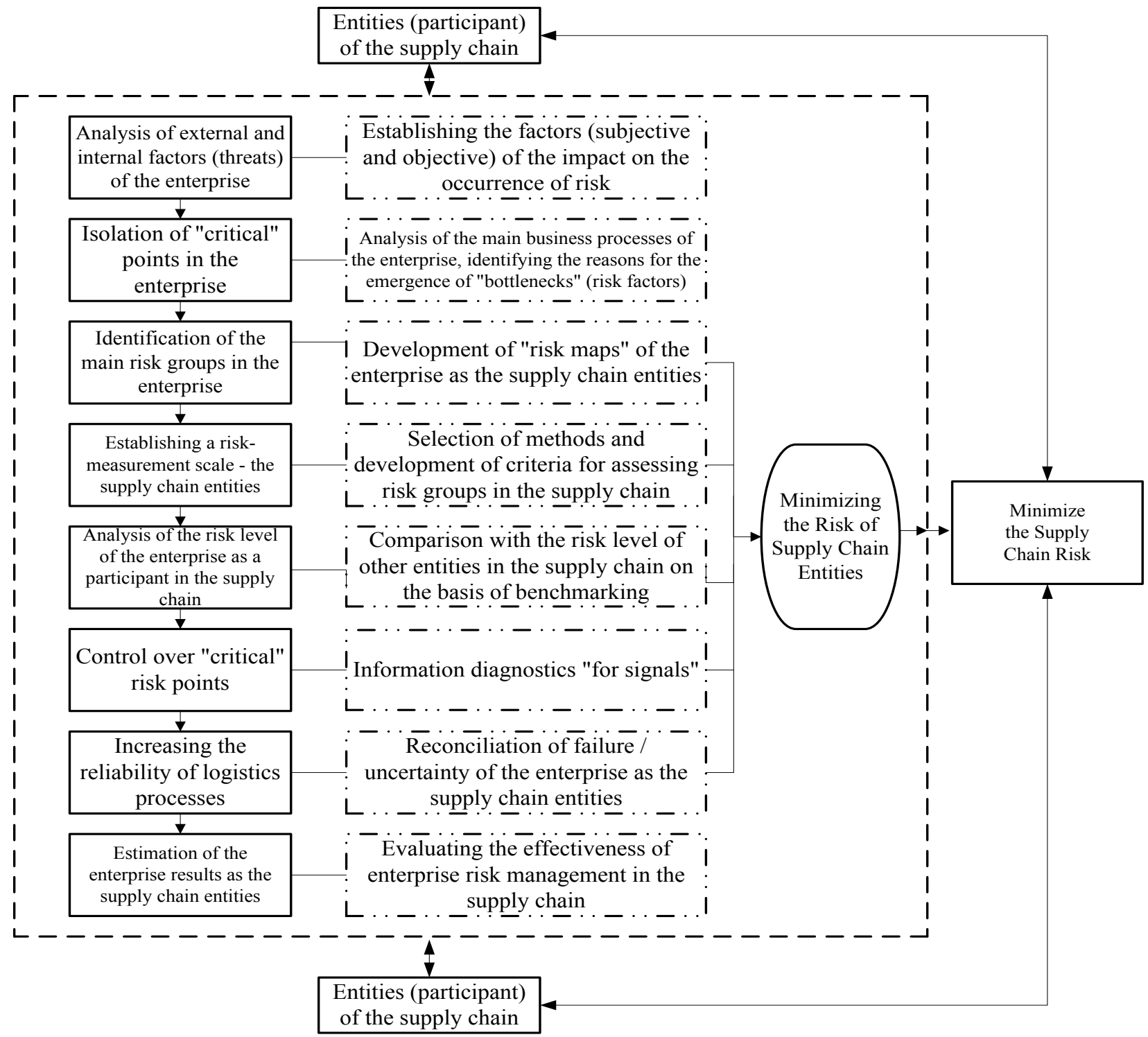

Fig. 10. Scheme of processes in the Adaption System to Risk Situations in the supply chain

Source: own research 
of actions associated with the coordination of flow processes between different elements - links of this form, and combining their interaction in accordance with the target system settings.

Integration as the principle of interaction in SCM can be considered at three levels. Integration of business processes at the micro-level is based on the principles of strategic interaction between the Focus Company and suppliers and customers. At the meso level, there is an integration of economic entities in the field of logistics services. There are various forms of integration: informal relations, formal relations, strategic alliances, virtual enterprises. At the macro-level, the idea of global integration of counterparties from different supply chains is to create a single information system for the search and management of data on sales and stocks of all counterparties participating in the system. At present, a new concept of consumption of a mass product is developing in the information market. Within this concept, shared, remote resources provide the ability to scale calculations over networks in the form of paid services.

The proposed Adaption System to Risk Situations will allow quickly tracking the appearance of various types of risks. This, in the future, makes it possible to quickly adapt to the company, as well as to adjust its supply strategy in order to minimize the negative consequences. The research has proved the consideration of many factors and variability of risk situations, the complexity, and simplicity of their measurement, the validity, and cost of potential losses for the enterprise in the future. The verification of the reliability of the proposed system with the help of simulation allowed identifying the most significant risk factors and measuring their impact on the effectiveness of managerial decisions of the logistics enterprise.

\section{References:}

Chuhray, N., Hirna, O. Formuvannja lancjuga postavok: pytannja teorii ta praktyky [Formation of Supply Chain: Questions of Theory and Practice], Lviv: Intellect-West, pp. 16-17. (In Ukrainian)

Gattorna, J. (1998) Strategic Supply Chain Alignment: Best practice in supply chain management. Aldershot: Gower, pp. 67.

Harrison, A.,Hoek, R. (2007) Upravlinnjalogistykoju: Rozrobka strategijlogistychnyhoperacij [Logistics Management and Strategy], Dnipropetrovsk: Balance Business Books, pp. 92-107. (in Russian)

Harvard Business Review (2008) Kak organizovat cepochku postavok [On Supply Chain Management], Moscow: Alpina Business Books, pp.97-119. (in Russian)

Krikavskij, E.V. (2006) Logistyka. Osnovy teorii [Logistics. Basic Theory], Lviv: Lviv Polytechnic National University (Information and Publishing Center "INTELEKT +"), Institute of Postgraduate Education, Intellect-West, pp. 393-395. (In Ukrainian)

Lukinskiy, V.S., Panova, Y.N., Strimovskaya, A.V. (2017) Integrirovannoe upravlenie tsepyami postavok: teorii, modeli i metody [Integrated Supply Chain Management: Theories, Models and Methods]. Logistics and Supply Chain Management, vol. 3, no. 80, pp. 40-56. (in Russian)

Lysons, K., Gillinham, M. (2012) Upravlenie zakupochnoy deyatelnostyu i tsepyu postavok [Purchasing and Supply Chain Management], Moscow: INFRA-M, pp.389. (in Russian)

Potaman, N.V. (2013) Kontseptsiya povysheniya effektivnosti upravleniya tsepyami postavok [The Concept of Improving the Efficiency of Supply Chain Management]. Proceedings of the National Technical University "KPI". Series: New solutions in modern technologies, no. 56, pp. 88-92. (in Russian)

Remyha, Y.S. (2013) Sozdanie mehanizma upravlenija riskami v cepochkah postavok [Establishment of a Risk Management Mechanism in Supply Chains]. Logistic Systems in Global Economy. Proceedings of International scientific-practical conference (Russia, Krasnoyarsk, March 14-15 March, 2013) (eds. Loginov Y.Y., Belyakova E.V.), Krasnoyarsk: Siberian State Aerospace University, pp. 194-197.

Sabatkoev, T.R., Sultanov, R.R. (2012) Budushhee cepej postavok v integracii na makro-urovne [The future of supply chains in macro-level integration] Logistika i upravlenie cepjami postavok (electronic journal), vol. 2, no. 49, Retrieved from: http://www.lscm.ru/index.php/ru/po-godam/item/795 (accessed 15 January 2018) (in Russian) Sergeev, V.I. (ed.) (2005) Innovacionnye tehnologii v logistike i upravlenii cepjami postavok [Innovative Technologies in Logistics and Supply Chain Management], Moscow: SCM Consulting, pp. 65-80. (in Russian)

Smirnova, E.A. (2009) Upravlenie tsepyami postavok: integratsiya i tamozhennoe administrirovanie [Supply Chain Management: Integration and Customs Administration], St. Petersburg: St. Petersburg State University of Economics and Finance, pp. 58-60. (in Russian)

Stock, J.R., Lambert, D.M. (2005) Strategicheskoe upravlenie logistikoj [Strategic Logistics Management], Moscow: INFRA-M, pp. 58-76. (in Russian)

Svon, M. (2017) Blokcheyn: Skhema novoy ekonomiki [Blokchain: Scheme of a new economy], Moscow: OlimpBusiness Publishing House, pp. 189-190. (in Russian)

Vitlinskiy, V.V., Velikoivanenko, H.I. (2004) Ryzykologija v ekonomici ta pidpryjemnyctvi [Risk in Economics and Entrepreneurship], Kyiv: KNEU, pp. 48-55. (In Ukrainian)

Volkov, V.D. (2011) Sistemno-operatsionnye osnovy informatsionnoy i transportnoy logistiki $v$ multimodalnykh $i$ mezhdunarodnykh perevozkakh [System-operational basis of information and transport logistics in multimodal and international transport] (PhD Thesis), Moscow, pp. 311-315. (in Russian) 